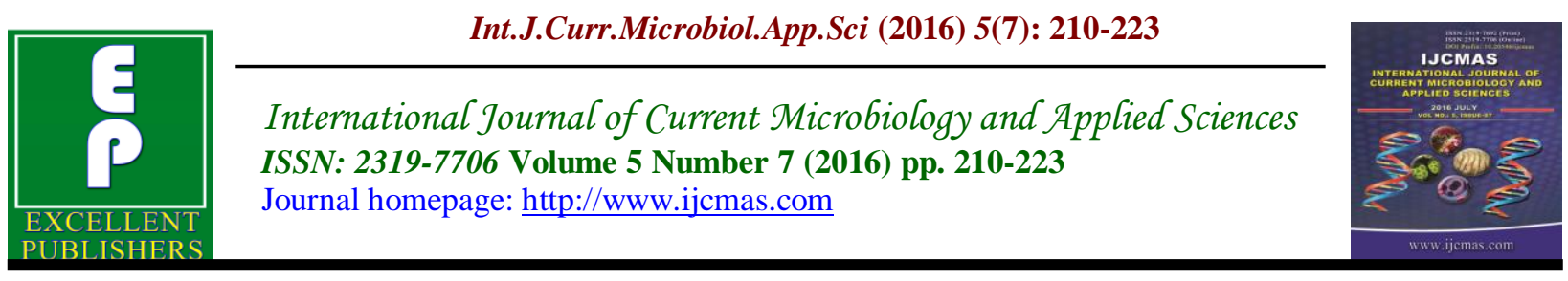

Original Research Article

http://dx.doi.org/10.20546/ijcmas.2016.507.022

\title{
Effect of Sanitizers and Glucose on Clostridium perfringens Biofilm Formation and Growth
}

\section{Castro Melina Gabriela ${ }^{1}$, Icazatti Alejandro², Divizia Julia², Vega Alba Edith², Cortiñas Teresa Ines ${ }^{2}$ and Stagnitta Patricia Virginia ${ }^{2} *$}

\author{
${ }^{1}$ Laboratory of Microbiology, University of San \\ Luis, Ejercito de Los Andes 950 Bloque I, San Luis, Argentina \\ ${ }^{2}$ Ejército de Los Andes 950 Bloque I Laboratory of Molecular Biology, IMIBIO, \\ National University of San Luis, Argentina \\ *Corresponding author
}

\begin{abstract}
A B S T R A C T
Keywords

Biofilm,

C. perfringens, sanitizers,

glucose, morphology,

CcpA, cpe.

\section{Article Info}

Accepted:

12 June 2016

Available Online:

10 July 2016

Clostridium perfringens enterotoxigenic strain is one of the responsible of food poisoning; this is caused by cpe enterotoxin. Cpe is produced during sporulation, a resistance mechanism. It is described that $C$. perfringens can form biofilm under stressed environments and this depends of carbohydrates availability. The aim of this work was to evaluate the ability of enteroxigenic $\left(\mathrm{E}^{+}\right)$and no enterotoxigenic $\left(\mathrm{E}^{-}\right)$C. perfringens strains to form biofilm at different concentrations of carbon source and the inhibitory effect of various Poli $\mathrm{P}$ over biofilm formation and the expression of cpe and ccpa genes. Our results indicate that $\mathrm{E}^{+} C$. perfringens biofilm reach the more complex structure with high glucose concentrations. Even more current sanitizers used in food industry like SAPP and TSPP, showed to stimulate biofilm formation and to inhibit the growth of planktonic cells. On the other hand, morphological changes were observed during biofilm formation under low glucose concentration and in presence of sanitizers. We propose that the change from a bacillary to coccoid form is related to a resistance to stressed environments. Finally the cpe expression is not related to biofilm formation.
\end{abstract}

\section{Introduction}

Clostridium perfringens is a Gram-positive anaerobic, spore forming, rod-shaped bacteria that commonly found in the gastrointestinal tract of both humans and animals. The microorganism causes toxinmediated diseases, including gas gangrene (clostridial myonecrosis), food poisoning and necrotizing enterocolitis in humans (Radhika et al., 2016). Also, necrotic enteritis or pigbel of the tribes of Papua New Guinea (Smedley et al., 2004).
C.perfringens poisoning can be caused by ingestion of food containing $\geq 5 \mathrm{log}$ vegetative cells/g of food of an enterotoxigenic strain. The poisoning is characterized by diarrhea and abdominal pain, symptoms that are detected 6-24 $\mathrm{h}$ after ingestion of contaminated food (Shandera et al., 1983).

This pathogen is classified based on the production of 4 major toxins: type $A(\alpha)$, 
type $\mathrm{B}(\alpha, \beta, \varepsilon)$, type $\mathrm{C}(\alpha, \beta)$, type $\mathrm{D}(\alpha, \varepsilon)$ and $E(\alpha, 1)$. The $5 \%$ of the strains produces an enterotoxin (CPE) encoded by the cpe gene (Czeczulin et al., 1993). This gene can be located in the chromosome or in a plasmid, and its location could define the type of disease produced. (Sparks et al., 2001; Shandera et al., 1983; Brynestad et al., 2001; Collie and McClane, 1998; Cornillot et al., 1995). Strains with enterotoxin in chromosomal location, both vegetative cells and spores, display enhanced resistance to high temperatures, osmotic and nitrites stress than those with plasmidic cpe gene (Sarker et al., 2000; Li and McClane, 2006). CPE production is associated with sporulation both in vivo and in vitro (Tórtora, 1984; Tórtora et al., 1986; Rood and Cole, 1991; Fach and Popoff, 1997).

Previously studies performed with strains isolated from food in our laboratory, confirm that vegetative cells and endospores of enterotoxigenic strains are significantly more resistant to heat and osmotic/nitriteinduced stress than non-enterotoxigenic strains of $C$. perfringens (Abbona and Stagnitta 2016). Even more, it is know that $C$. perfringens can develop another resistant form: biofilm (Charlebois et al., 2014; Donelli et al., 2012). This gives the microorganism some of the resistance provided by the endospores, but the biofilm cells can adapt more quick to changes in the environment (Varga et al., 2008). Bacterial biofilms are communities of cells adhered to surfaces and embedded in a matrix of extracellular polymeric substances, nucleic acids and proteins (Yantorno et al., 2010). Bacteria that are part of the biofilm are termed sessile and are physiologically distinct from those which are suspended, called planktonic. Several studies suggest that biofilm maturation affects antibiotic resistance and sanitizers through different mechanisms (Wang et al., 2014, Charlebois et al., 2014). It has been reported that biotypes A of ATCC 13124, 13, and SM101, as well as type $\mathrm{C}, \mathrm{D}$, and $\mathrm{E}$ strains of $C$. perfringens can form biofilm (Varga et al., 2008) and the persistence in the intestine forming biofilm could explain the establishment of Antibiotic Associated Diarrhea (AAD) after damage in the normal flora by antibiotics. There are evidence that shows that $C$. perfringens biofilm is present in gut mucosal Microbiotas of Ulcerative Colitis patients. (Fite et al., 2013)

The regulation of biofilm production in Gram-positive bacteria is due to many factors, one of which is the availability of carbohydrates in the medium (Varga et al., 2008).

The catabolite control protein A (CcpA) belongs to the family of regulators LacI/GalR and acts as a global transcriptional regulator in response to limitations of carbohydrates. $C$. perfringens CcpA protein is a protein of 332 amino acids, whose gene coding exhibits the highest level of identity (70\%) with CcpA orthologous genes from other clostridia (Bruggemann et al., 2003).

The sanitizers are used to reduce food spoilage by microorganisms. Sanitation reduces the number of microorganisms to a safe level to health. The presence of biofilm or spores makes hard to sanitize since they become resistant to chemical attack by the detergent. In addition, biofilm may attract other pathogenic bacteria. Although a large number of chemical preservatives have been proved to protect edible products, only a relatively small number of them are allowed to be used as such. It is due to antimicrobial activity that they keep in in vitro assays, but not when they are added to the food (Jay et al., 2005). FDA (Food and Drug Administration) regulates this issue allowing 
the Compounds Generally Recognized As Safe (GRAS) to be used as additives and sanitizers.

Inorganic polyphosphates (Poly P) are GRAS compounds and are widely used as food additives in meat and dairy industry to improve functional properties, retard oxidative rancidity, protect flavor, increase productivity due to its water binding ability and improve emulsification properties of the food. There are several studies establishing that Poly $\mathrm{P}$ are growth inhibitors of various pathogenic microorganisms (Akhtar et al., 2008). The suggested inhibition mechanism indicates that Poly $\mathrm{P}$ would bind to the cell wall, chelating metals such as $\mathrm{Ca}^{2+}$ and $\mathrm{Mg}^{2+}$ held together without releasing them, this would cause bactericidal or bacteriolytic effects. At high temperatures Poly P lose its chelating ability and it turns into orthophosphate (Molina Ubeda and Diaz; 2002). Indirectly, Poly P block the dynamics of $\mathrm{Z}$ ring formation and in this way they act directly on bacterial cell division inhibition (Maier et al., 1999).

The aim of this work was to evaluate the ability of enteroxigenic and no enterotoxigenic $C$. perfringens strains to form biofilm at different concentrations of carbon source and to evaluate the inhibitory effect of various Poly $\mathrm{P}$ on biofilm already formed and the expression of cpe and cсpa genes.

\section{Materials and Methods}

\section{Strains, Media and Culture conditions}

Enterotoxigenic $\left(\mathrm{E}^{+}\right)$and nonenterotoxigenic $\left(\mathrm{E}^{-}\right) C$. perfringens strains isolated from meat foods in San Luis, Argentine were used in this study. The strains were previously characterized by our group by reversed passive latex agglutination (RPLA) and PCR for enterotoxin (CPE) and cpe gene detection respectively (Corigliano et al., 2011; Stagnitta et al., 2006).

The strains were conserved in cooked meat medium (CMM) at room temperature, and biofilm formation were obtained in clostridia optimized medium (COM) (p/v); (i) , $2 \%$ peptone , $0.5 \%$ yeast extract, $0.15 \%$ $\mathrm{MgCl}_{2}, 0.075 \%$ cysteine hydrochloride, (ii). Glucose $\quad 0.5 \% \quad$ (iii). $\quad 0.5 \%$ dipotassium phosphate, $\mathrm{pH} 7.2$.

\section{Biofilm}

Biofilm formation was determined by measuring sessile/planktonic cells ratio (Abs570/OD580). For each experiment 10 Petri dishes provided with 5 coverslips (1.8 $\mathrm{x} 1.8 \mathrm{~cm}$ ) placed in their base were used with $10 \mathrm{ml}$ of COM. The inocula were obtained in COM at logarithmic phase of growth (5-7 h of incubation) with an initial concentration of OD580nm $=0.2\left(10^{8}\right.$ $\mathrm{CFU} / \mathrm{ml}$ ). The plates were incubated at $37^{\circ} \mathrm{C}$ in anaerobic jar under an atmosphere of $9 \% 5$ $\mathrm{N}_{2}: 5 \% \quad \mathrm{CO}_{2}$. The biofilm growth was determined at different incubation periods (24 to 216h).

The quantification of sessile cells was determined with $0.1 \%$ crystal violet for 20 min and after 30 min discoloration with cold methanol. The Abs of the extracted dye was measured at $570 \mathrm{~nm}$ in spectrophotometer. Planktonic cells were determinated by measurements of OD 580nm.

\section{Viable count of sessile and planktonic cells}

Viable count cells adhered to the coverslips were washed with saline solution (SS) and removed by vortex. The cells were seeded in Sodium Sulphite-Polymyxin-Sulfadiazine 
Agar (SPS). The plates were incubated at 37 ${ }^{\circ} \mathrm{C}$ in anaerobic atmosphere for $24 \mathrm{~h}$ and the results were expressed as $\mathrm{CFU} / \mathrm{cm}^{2}$. Dilutions of planktonic cells were seeded in SPS medium and cultured in the same conditions previously described and the results expressed as CFU/ml.

\section{Most probable number (MPN)}

The viability of planktonic cells was also quantified by the MPN technique, using milk- $\mathrm{Fe}^{2+}$ medium. The cultures were incubated for 16 to $18 \mathrm{~h}$ at $45{ }^{\circ} \mathrm{C}$. The reaction was considered positive when milk coagulation and iron oxidation was observed. The total number of viable bacteria was determined using the table of Man (Man 1983 Corrected)

\section{Biofilm observation}

\section{Optical microscopy}

The coverslips were washed, fixed and colored with $0.1 \%$ crystal violet for $20 \mathrm{~min}$. It was observed by light microscopy at 40 and 100x amplification.

\section{Scanning electron microscopy (SEM)}

Biofilm coverslips were fixed with methanol for $30 \mathrm{~min}$ and dehydrate for $24 \mathrm{~h}$ at $37^{\circ} \mathrm{C}$ and were mounted on aluminum stubs, covered with gold with a standard sputter coater and then photographed with a Zeiss LEO 1450VP. Photos of scanning electronic microscopy (SEM) were conducted at 'Laboratorio de Microscopía Electrónica y Microanálisis' (LABMEM) of Universidad Nacional de San Luis (Argentina).

Effect of glucose concentration on the formation of biofilm

The effect of the concentration of the carbon source was carried out using COM and modificated using $0.1 \%$ and $\% 1$ glucose and other culture conditions previously described (Varga et al., 2008).

\section{Preparation of polyP solutions}

Tetra Sodium Pyrophosphate (TSPP), Sodium Tripolyphosphate (STPP) and Sodium Acid Pyrophosphate (SAPP) from Sigma, all were dissolved in distilled water to a final concentration of $10 \%(\mathrm{w} / \mathrm{v})$, adjusted to $\mathrm{pH}$ 7.0, filter sterilized and stored at $4{ }^{\circ} \mathrm{C}$ for no more than 1 month.

\section{Inhibitory effect of sanitizers SAPP,} STPP and TSPP on biofilm growth

The inhibitory effect of SAPP, STPP and TSPP on the biofilm obtained after $48 \mathrm{~h}$ of incubation was determined. The experiments were carried out in COM medium with 0.4 , 0.6 and $0.8 \%$ of polyphosphates. The effect of sanitizers on biofilm at 6, 24 and 48 h of treatment was determined.

\section{Effect of $\mathrm{Mg}^{2+}$}

The effect of the concentration of $\mathrm{Mg}$ ions in the inhibitory mechanism of sanitizers was determined in the absence and presence of $0.15 \% \mathrm{MgCl}_{2}$ in $\mathrm{COM}$ added of $0.8 \% \mathrm{SAPP}$ and $0.8 \%$ TSPP.

Expression of $\operatorname{ccp} A$ and $c p e$ in sessile and planktonic cells by RT-PCR

RNA extraction was performed by a rapid method for Gram positive bacteria (Oh and So 2003); using glass beads (106 microns, Sigma). RNA integrity was determined by gel electrophoresis in $1 \%$ agarose at 80 volt. And RNA was quantified in Beckam DU600

The cDNA was obtained using Cloned Avian Myeloblastosis Virus (AMV) Reverse 
Transcriptase (RT) (Invitrogen). The reaction mixture: $2.8 \mathrm{mM}$ RNase -free water, 0.1-0.5 ug RNA, $0.02 \mathrm{mM}$ hexamer primers, final volume of $20 \mathrm{ul}$ was used and incubated during $5 \mathrm{~min}$ at $70{ }^{\circ} \mathrm{C}$. Buffer $5 \mathrm{X}$ reverse transcriptase kit, $1 \mathrm{mM}$ dNTPs, $0.25 \mathrm{~mm}$ ribonuclease inhibitor and $\mathrm{ddH} 2 \mathrm{O}$ was then added. It was incubated for $5 \mathrm{~min}$ at $25^{\circ} \mathrm{C}$. $1 \mathrm{ul}$ of AMV reverse transcriptase enzyme was added and incubated for $10 \mathrm{~min}$ at 25 ${ }^{\circ} \mathrm{C}, 60 \mathrm{~min}$ at $42{ }^{\circ} \mathrm{C}$ and $10 \mathrm{~min}$ at $70{ }^{\circ} \mathrm{C}$.

For the following PCR reaction mixture was used: 1X buffer, $0.2 \mathrm{mM}$ dNTP, $1.5-3 \mathrm{mM}$ $\mathrm{Mg}^{2+}, 0.2 \mathrm{mM}$ Primer forward, $0.2 \mathrm{mM}$ Primer reverse, ddH2O, $1.5 \mathrm{U}$ of $\mathrm{Taq}$ polymerase, and 5 ul of cDNA. Primer sequence is listed in Table 1.

The protocol used was: $94{ }^{\circ} \mathrm{C}$ for $5 \mathrm{~min}, 40$ cycles of $94{ }^{\circ} \mathrm{C}$ for $45 \mathrm{sec}, 50{ }^{\circ} \mathrm{C}$ for $1 \mathrm{~min}$ and $72{ }^{\circ} \mathrm{C}$ for $1 \mathrm{~min}$. The final extension was at $72{ }^{\circ} \mathrm{C}$ for $7 \mathrm{~min}$. The PCR products were determined by gel electrophoresis in $1.8 \%$ agarose at 80 volts for $40 \mathrm{~min}$ and compared with Molecular Wight Ladder.

\section{Quantitative Data Analysis}

Data are expressed as mean \pm SEM from three independent experiments. Statistical analysis was performed using the Infostat software version 2012 and GraphPad Prism5 software version 5.01. $\mathrm{p} \leq 0.05$ and $\mathrm{p} \leq 0.001$ compared to controls no treated, were considered as significant difference (Di Renzo et al., 2012).

\section{Results and Discussion}

\section{Effect of glucose concentration on biofilm formation}

A significant increase in Abs/OD ratios of $\mathrm{E}^{+}$strain until $120 \mathrm{~h}$ incubation at three glucose concentrations was observed. These ratios diminished after incubations longer that $120 \mathrm{~h}$. Biofilm formation significantly decreased with glucose concentration $1 \%$ vs $0.5 \%(\mathrm{P} \leq 0.05)$ and vs $0.1 \%(\mathrm{P} \leq 0.01)$ at $120 \mathrm{~h}$ (Fig. 1A, 1B). Statistical analysis using Pearson coefficient established an inverse correlation between glucose concentration and biofilm formation (-0.59). (Two way ANOVA, GraphPad Prism 5 and Infostat. A similar effect was seen in $\mathrm{E}$ strain (Fig. 1C, 1D).

In order to elucidate if the glucosedependent biofilm growth is related to $c c p A$ expression, we analyzed the $C$. perfringens mRNA by RT-PCR. The results indicate that cсpA is expressed at the beginning of biofilm formation (24h) and two days later its expression decreases. Interestingly, planktonic cells do not express $c c p A$ at $24 \mathrm{~h}$, but at $72 \mathrm{~h}$ of incubation (Fig. 2).

Effect of sanitizers SAPP, STPP and TSPP on $\mathrm{E}^{+}$biofilm and planktonic cells growth

The inhibitory effect of sanitizers was studied on both planktonic and sessile cells. OD decreased on planktonic cells treated with $0.6,0.8 \%$ SAPP $(\mathrm{p} \leq 0.05)$ and $0.8 \%$ TSPP ( $\leq 0.05)$ until 48h. Any sanitizer caused a total inhibition of the planktonic cells growth. Interestingly STPP did not caused OD diminution of the $C$. perfringens cells.

The inhibitory effect of the sanitizers on sessile cells was determined on mature biofilms. The effect of $0.4,0.6$ y $0.8 \%$ SAPP, TSPP and STPP after $120 \mathrm{~h}$ of treatment was determined. The ratio Abs/OD averages obtained after all treatment were as follows $0.83,0.8,0.28$, and 0.22 (TSPP, SAPP, STPP and control, respectively) (Fig. 3). 
This effect was confirmed by Bonferroni test for TSPP and SAPP $(0.4 \%$ and $0.8 \%)$ meanwhile after treatment with STPP no significant differences with control were observed.

On the other hand the increased growth seen with Crystal Violet stains was correlated with the Abs/OD ratios. Interestingly some sanitizers stimulated biofilm growth, and decreased OD planktonic measures. This suggest that planktonic cells in suspension attach to the biofilm through time. (Fig. 4)

To rule out an unwanted effect by the sanitizers- $\mathrm{Mg}^{2+}$ complexation, we performed an experience in absence of $\mathrm{Mg}^{2+}$. Statistical analysis on Abs/OD ratio showed no significant difference between the treatments and controls through time (Data not shown).

\section{Viability of planktonic and sessile cells}

In order to see if the planktonic and sessile cells were alive, we preformed two methods to measure this. The counted cell assay of treatments with $0.8 \%$ TSPP and $0.8 \%$ SAPP showed a big inhibition on sessile and planktonic cells, while $0.6 \%$ SAPP did not affect $C$. perfringens viability at $72 \mathrm{~h}$. Surprisingly $0.8 \%$ SAPP increased CFU counted at $72 \mathrm{~h}$ (Fig. 5) and OD at $120 \mathrm{~h}$ (Fig. 3). This could be explained by sanitizer metabolization and loss of effect.

Therefore SAPP stimulated biofilm growth and affected bacteria viability in a concentration and time-dependent way. On the other hand TSPP stimulated biofilm growth, but diminished $C$. perfringens viability with all concentration tested for a long time. It is notable to mention that TSPP affects planktonic CFU two times more than sessile CFU (Fig. 5). These results were confirmed with a more sensitive method (MPN) (Data not shown). Changes of $C$. perfringes morphology in biofilm. During biofilm formation, $C$. perfringens cells showed morphological changes from bacillary to coccoid forms depending on the glucose concentrations assayed.

In Crystal Violet staining, biofilm showed increased number of coccoid forms with $0.1 \%$ glucose treatment through time; $28 \%$ and $39 \%$ at 24 and $72 \mathrm{~h}$ respectively. The most remarkable morphological changes were observed at $0.5 \%$ glucose $8.7 \%$ and $81.2 \%$ at 24 and $72 \mathrm{~h}$ respectively. While at $1 \%$ glucose the number of bacteria with coccoid forms was significant lower than those with bacillary forms, $3.9 \%$ and $2.7 \%$ at 24 and $72 \mathrm{~h}$.

The $\mathrm{E}^{-}$strain cultured with $0.1 \%$ glucose presented $41 \%$ and $66 \%$ of coccoid forms at 24 and $72 \mathrm{hs}$ respectively. With $0.5 \%$ glucose coccoid forms were significatively represented with a $71 \%$ and $56 \%$ at 24 and $72 \mathrm{~h}$ respectively. And with $1 \%$ glucose the biofilm presented $4.06 \%$ and $2.9 \%$ of coccoid forms at 24 and $72 \mathrm{~h}$.

There was not significative difference between coccoid percentages in both strains. But coccoid forms of $\mathrm{E}^{+}$strain increased through the time with $0.5 \%$ glucose.

The formation of a gel layer on the biofilm in the presence of SAPP $0.8 \%$ and TSPP $0.4 \%$ and $0.8 \%$ was detected, distorting classical palisade arrangement as time increased (Fig. 4A).

Scanning electron microscopy (SEM) showed the presence of coccoid forms in control as well as in treated biofilm (Fig. 6A, 6B and 6D). At 48h biofilm treated with TSPP presented cells with the following lengths: 5,298 and 4,625 microns. Also the no treated photograph showed a flat surface biofilm and coccoid forms with the 
following lengths: 3,474 microns and 1,399 microns (48h); 4,126 x 1,411 microns and $2,397 \times 1,610$ microns $(24 \mathrm{~h})$.

To elucidate if the sanitizer precipitates on cells surface, turning them into characteristic forms, we observed by SEM the sanitizer in absence of bacteria, demonstrating the crystals formation (Fig. 6C). Surprisingly, the measure of the crystals were bigger than those seen with bacteria; indicating that sanitizer is deposited on the bacteria surface besides preforming specific structures.

On the other hand, the counted cells in SEM photographs showed that $C$. perfringens treated with TSPP and control biofilm presented $50 \%$ and $27 \%$ of coccoid forms respectively.

Monte et al., 2014 saw changes in Gram negative walls induced by vegetables extracts, so we suggest that stressful environments as glucose consumption and sanitizer treatment could affect $C$. perfringens wall. This could turn the common morphology on a resistant structure to keep the bacteria alive (Monte et al., 2014).

\section{cpe expression in $C$. perfringes biofilm}

Alternatively, to further inquire if biofilm formation is related to $C$. perfringens pathogenesis, we observed cpe expression in planktonic and sessile cells. There was no expression of cpe (Fig. 2). It is known that cpe production and secretion occurs in a sporulation-dependent way. We do not have indication that sporulation occurs during biofilm formation. But Pantaléon et al., proposed that the germination rate is lower in the spores isolated from the biofilm of Clostridium difficile in comparison with the spores purified in planktonic culture. This lower rate of germination may be due to the presence of a shroud present around the spores formed within the biofilm. This may prevent germination in the biofilm (Pantaléon et al., 2014).

The present study suppose that biofilm formation, sporulation and initiating TFPdependent gliding motility are all three responses to stressed environments. This could be CcpA dependent or CcpA independent. We think that in particular environments $C$. perfringens will decide which process is the most advantageous or possible combinations of them to survive.

On the other hand, sporulation process need a big consumption of energy and does not allow a quick adaptation to the environmental changes, as biofilm do.

It is important to note that cpe expression is absence in biofilm cells of $72 \mathrm{~h}$ growth. But it does not indicate necessarily the germination activation and cpe protein release.

Finally, Varga et al., 2004, reported that CcpA inhibits cpe expression during exponential phase of $C$. perfringens and under sporulation conditions CcpA leads to Sig E and Sig K synthesis stimulation cpe transcription during stationary phase. This may explain the absence of cpe expression in planktonic cells.

The present study results suggest that there is an inverse correlation between glucose concentration and biofilm formation in $\mathrm{E}^{+} C$. perfringens.In another hand $C c p A$ expression decreases with time in biofilm but planktonic cells. This result could be explained by two hypotheses: 1 . Taking in account bibliography, the availability of glucose activates CcpA and glucose availability decreases over time. This is due to increased glucose consumption, and the 
activation of $\mathrm{CcpA}$ is not essential. So it is not expressed at $72 \mathrm{~h}$ of biofilm formation. But it does not happen with planktonic cells, it seems to be that $\mathrm{CcpA}$ delays it expression, starting between 24 and $72 \mathrm{~h}$.

The hypothesis 2 is based on previous studies of Varga et al., (2008) which revealed that cсpa is expressed both in planktonic and sessile cells, being this essential for maximal biofilm formation of $C$. perfringens. Other studies suggest that CcpA negatively regulates its expression in Staphylococcus aureus strains (Canova et al., 2014). All this together suggest that the $\mathrm{CcpA}$ expression in biofilm since $24 \mathrm{~h}$ is expressed corresponding with maximal biofilm formation from $C$. perfringens; then it start to diminish its expression by negatively regulation.

Table.1

\begin{tabular}{|c|c|}
\hline Primers & Segment amplified \\
\hline $\begin{array}{l}\text { a) Fw5'-AGAAGCTGGAGTGTCAATAGCACCA- 3` } \\
\text { Rv 5 '-GTTAGCTACGTCCTCAGCACCTCT- 3`' }\end{array}$ & $c c p A$ (232 bp) (Primer- BLAST program) \\
\hline $\begin{array}{l}\text { b) Fw5 -TGTTAATACTTTAAGGATATGTATCC-3` } \\
\text { Rv } 5 ` \text { - TCCATCACCTAAGGACTG -3 }\end{array}$ & Cpe (935 bp) (Aguilera et al., 2005) \\
\hline $\begin{array}{l}\text { c) Fw5-TTTCGAAAGGAAGATTAATACC-3 } \\
\text { Rv5-CAACTTAATGGTAGTAACTAAC-3 }\end{array}$ & $16 S$ rRNA $(965 \mathrm{pb})$ \\
\hline
\end{tabular}

Primers sequences used to amplified $c c p A$, cpe and $16 s$ rRNA genes.

Fig. 1 Clostridium perfringens biofilm formation (Abs/OD) at different glucose concentration $(0.1 \%, 0.5 \%, 1 \%)$ in a enterotoxigenic strain $\mathrm{E}+(\mathrm{A})$ and non enterotoxigenic strain $\mathrm{E}-(\mathrm{C})$. Crystal Violet $0.1 \%$ stain of biofilm formation from $\mathrm{E}+(\mathrm{B})$ and $\mathrm{E}-(\mathrm{D}) *(\mathrm{P}<0.05) * *(\mathrm{P}<$ $0.01 \%)$.

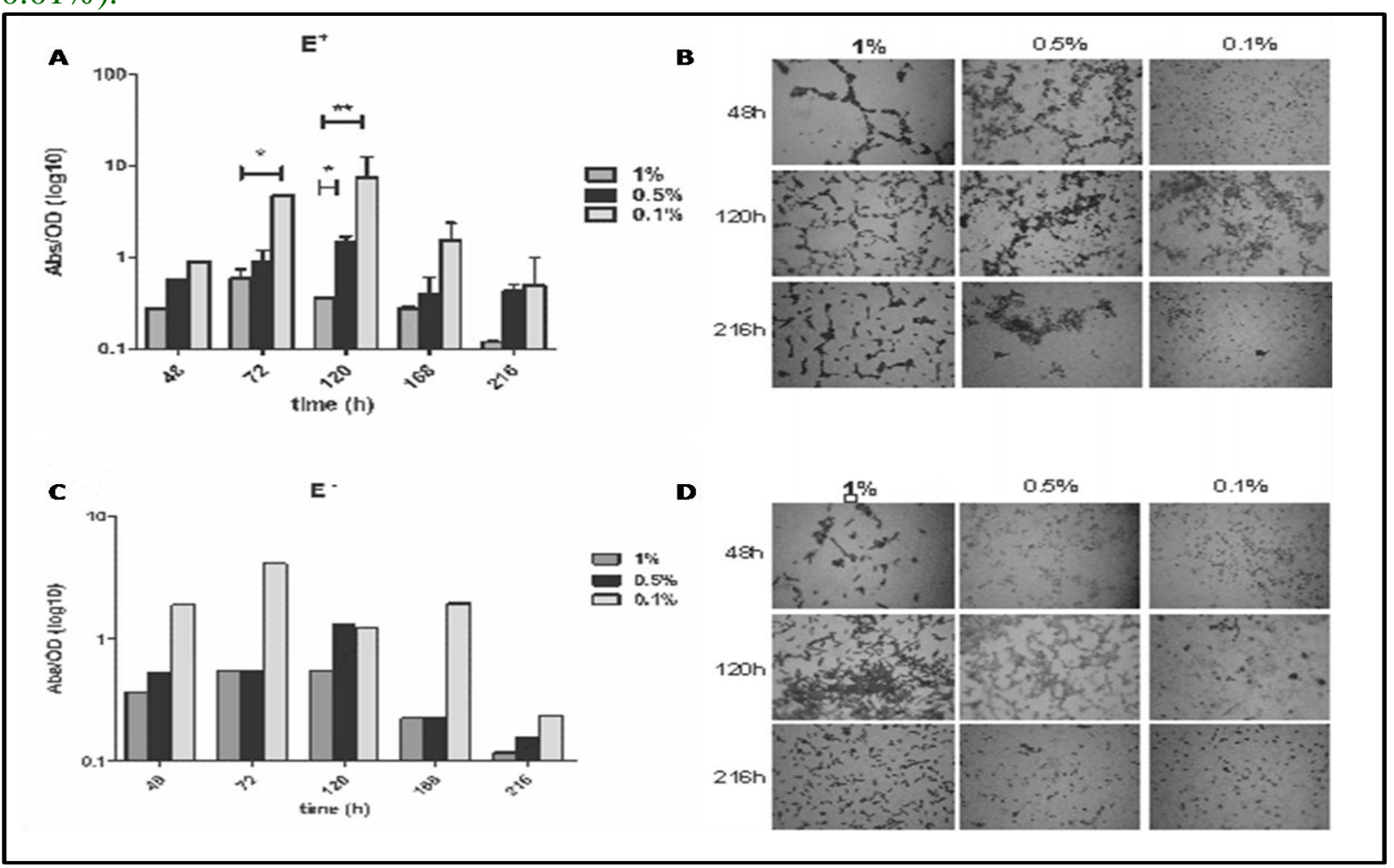


Fig. 2 RT-PCR from Planktonic (P) and sessile (B) cells mRNA at 24 and $72 \mathrm{~h}$ of biofilm formation.

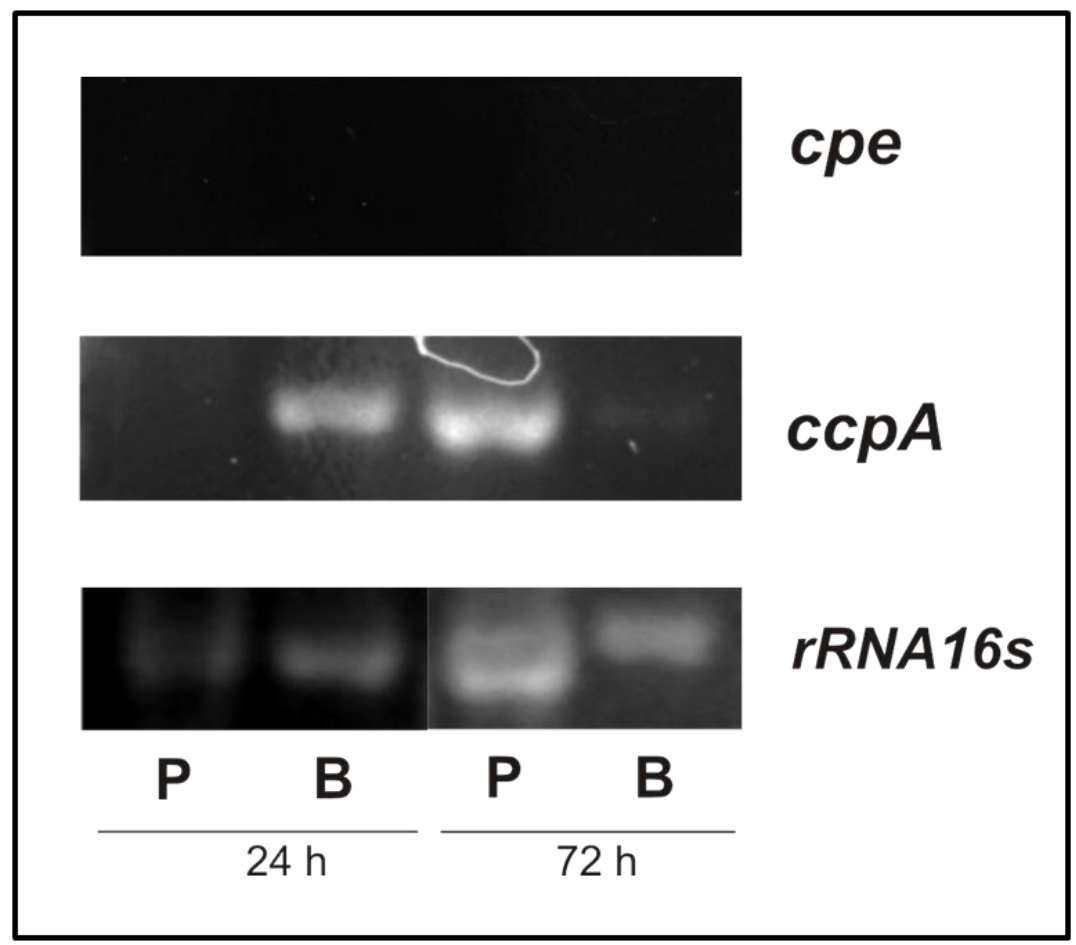

Fig. 3 Effect of sanitizers TSPP and SAPP on Optical Density (OD) of planktonic cells from C. perfringens $\mathrm{E}^{+}$strain

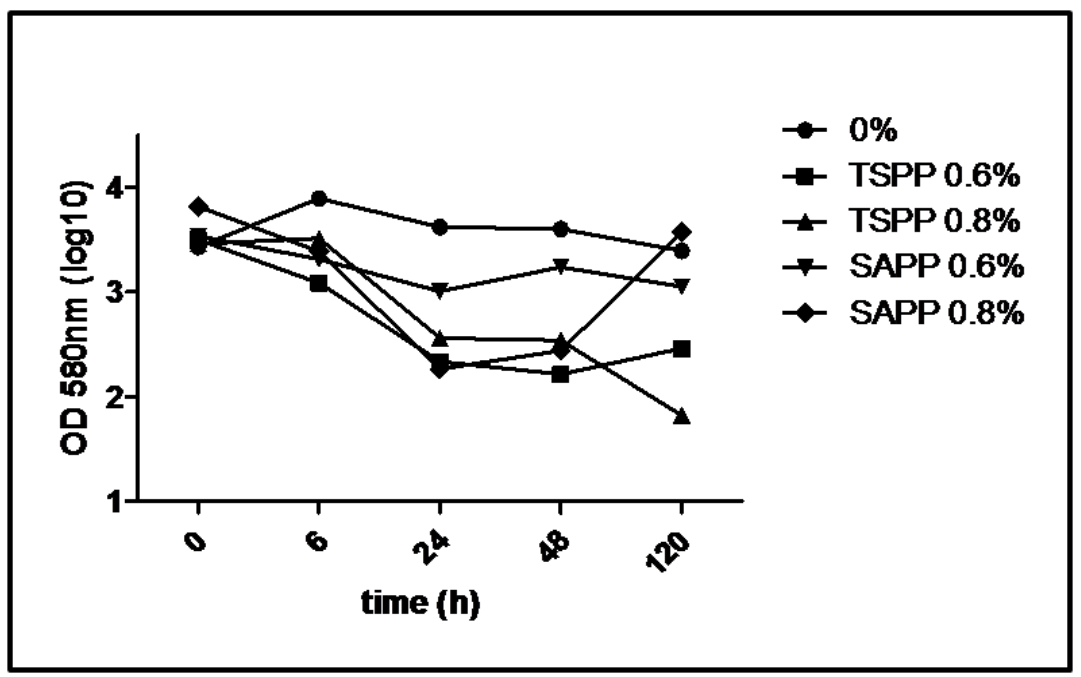


Fig. 4 Effect of sanitizers TSPP and SAPP on mature biofilm from C. perfringens $\mathrm{E}^{+}$strain. Crystal Violet $0.1 \%$ stain (A). Abs/OD ratio (B)

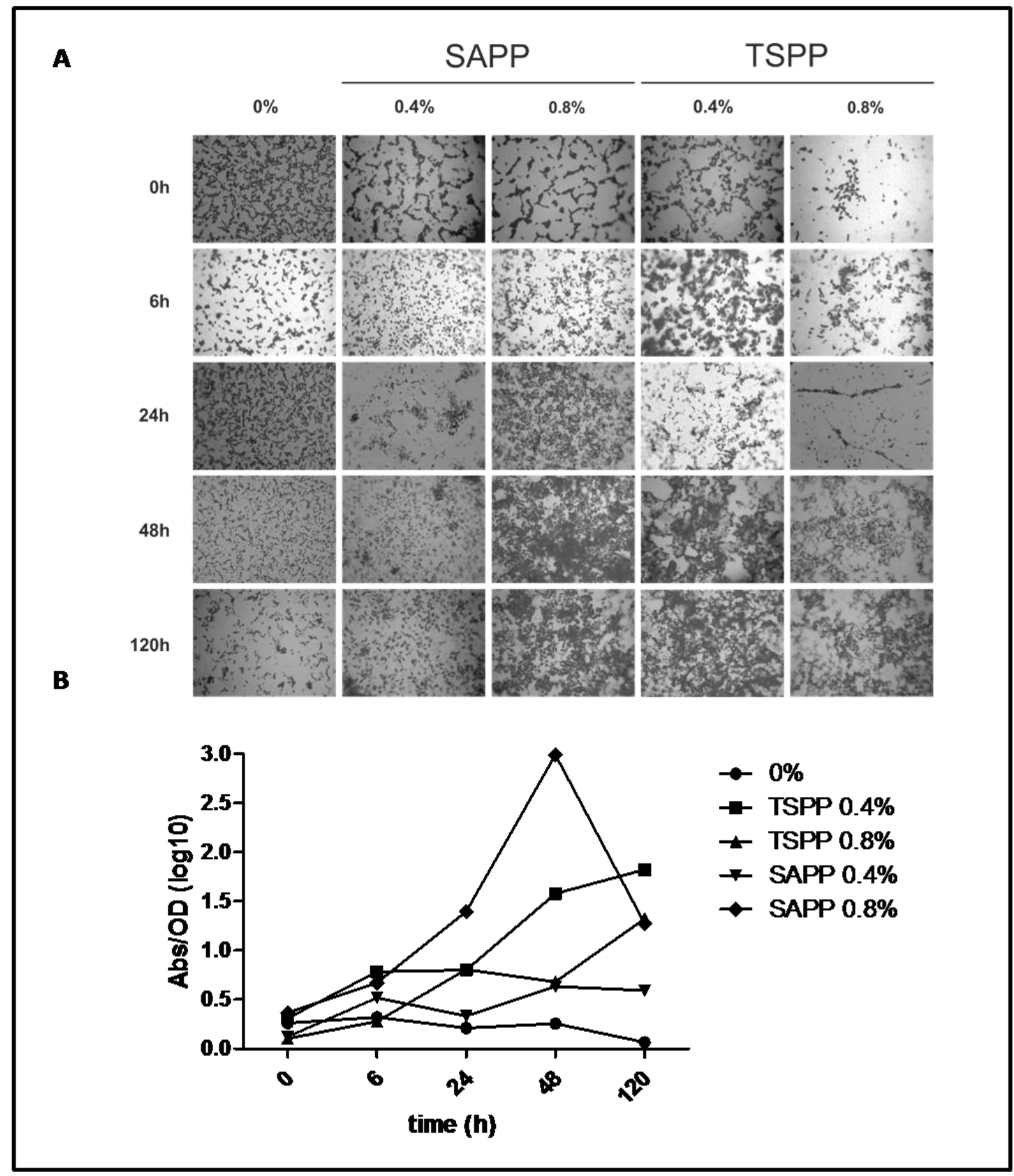


Fig. $5 \mathrm{CFU}$ from sessile and planktonic cells from a enterotoxigenic $C$. perfringens strain at $72 \mathrm{~h}$. $* \mathrm{p} \leq 0.05$ compared to no treated planktonic cells

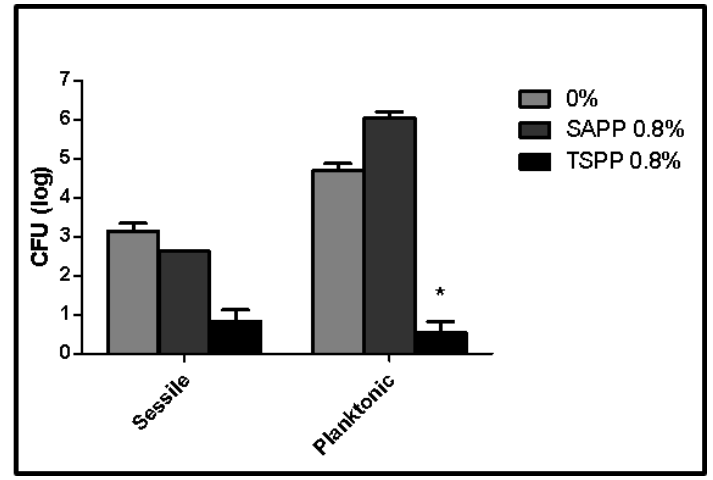

Fig. 6 SEM of a mature biofilm from an enterotoxigenic strain of $C$. perfringens A. $48 \mathrm{~h}$ TSPP $0.8 \%$ 5,298 and 4,625 microns B. 48h 0\% 3,474 and 1,399 microns C. 72h TSPP D. 24h 0\% 2,397 x 1,610 microns E. 24 h $0 \% 4,126$ x 1,411 microns.

A

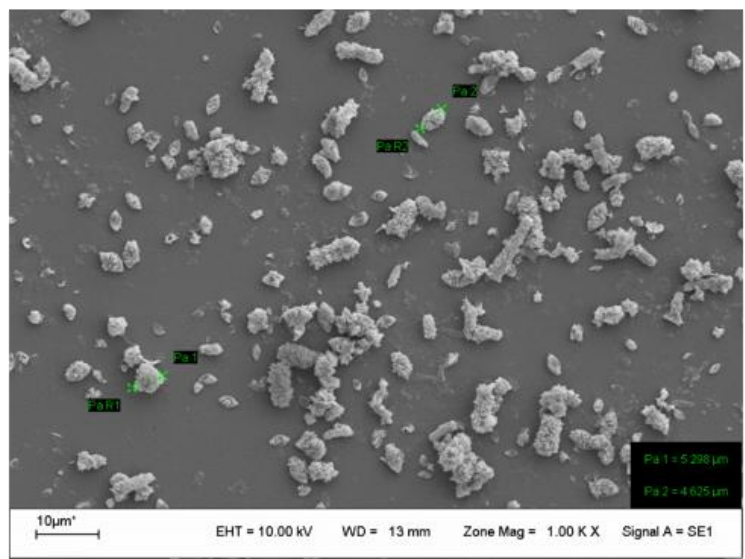

B

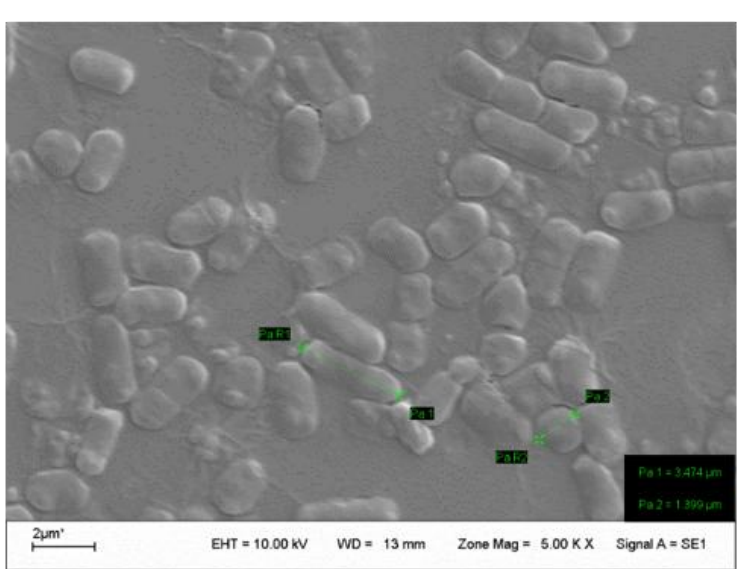

C

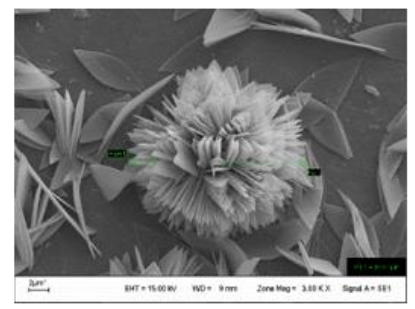

D

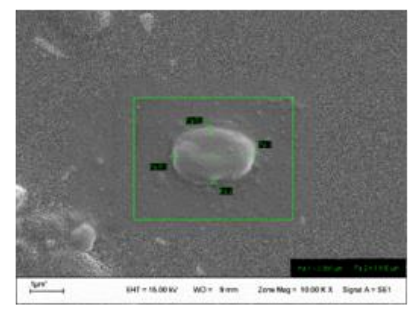

E

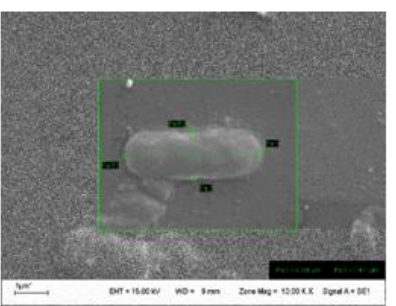


None of both hypotheses indicates any clue to elucidate why planktonic cells express cсpa before sessile cells. We think biofilm retains most nutrients, including glucose, being this necessary to survive in the sessile resistance form; so in this way when environmental conditions improve for its normal growth, it could be easy and fast to restore Clostridium perfringens metabolism.

On the other hand, only SAPP and TSPP produced a decrease in OD, but interestingly they stimulated biofilm structure growth. Furthermore, the viability of biofilm cells diminishes with SAPP and TSPP, so we suggest that the high values of Abs from biofilm treated with SAPP and TSPP correspond to the whole biofilm structure and the gel layer of sanitizer that could recruit some planktonic cells. Despite of this, we think this uncommon biofilm structure situated in an environment with other bacteria could recruit them and increase its pathological features. This is an important feature in biofilm pathogenesis, because this could provoke other bacteria attachment, and an increase in pathogenesis. Interestingly, the morphological changes observed at low glucose concentration for both strains ( $\mathrm{E}^{+}$and $\mathrm{E}^{-}$) could be due to a glucose consumption resistance, and could be related in some way with the formation of biofilm. Even more, we demonstrate that sanitizers promote coccoid forms. Glucose consumption and treatment with sanitizer are both features of a stressed environment for $C$. perfringens. Finally we suggest that the absence of cpe enterotoxin in planktonic and sessile cells can be explained to the absence of sporulation; which is essential for cpe release.

All this together, remark the importance of biofilm formation and complex structures in presence of sanitizers used to improve food quality, suggest a failure in this method used in industry. This could lead to increase pathogenesis of $C$. perfringens, helping to form mixed biofilm with other bacteria.

\section{Acknowledgments}

Financial support was provided by UNSL PROICO 2-0914.

\section{References}

Abbona, C.C., and P.V. Stagnitta. 2016. "Clostridium perfringens: Comparative effects of heat and osmotic stress on non-enterotoxigenic and enterotoxigenic strains." Anaerobe .39: 105-113. doi: 10.1016/j.anaerobe.2016.03.007.

Aguilera, M.O., P.V. Stagnitta, B. Micalizzi, and A.M. de Guzmán. 2005. "Prevalence and characterization of Clostridium perfringens from spices in Argentina." Anaerobe, 11(6): 327-34. doi: 10.1016/j.anaerobe.2005.05.003.

Akhtar, S., D. Paredes-Sabja, and M.R. Sarker. 2008. "Inhibitory effects of polyphosphates on Clostridium perfringens growth, sporulation and spore outgrowth." Food Microbiol., 25(6): $\quad 802-8$. doi: 10.1016/j.fm.2008.04.006.

Bruggemann, H., S. Baumer, W.F. Fricke, A. Wiezer, H. Liesegang, I. Decker, C. Herzberg, R. Martinez-Arias, R. Merkl, A. Henne, and G. Gottschalk. 2003. "The genome sequence of Clostridium tetani, the causative agent of tetanus disease." Proc. Natl. Acad. Sci. U S A, 100(3): 1316-21. doi: 10.1073/pnas.0335853100.

Brynestad, S., M.R. Sarker, B.A. McClane, P.E. Granum, and J.I. Rood. 2001. "Enterotoxin plasmid from Clostridium perfringens is conjugative." Infect. Immun., 69(5): 3483-7. doi: 10.1128/IAI.69.5.3483-3487.2001.

Canova, M.J., G. Baronian, S. Brelle, M. CohenGonsaud, M. Bischoff, and V. Molle. 2014. "A novel mode of regulation of the Staphylococcus aureus Vancomycinresistance-associated response regulator 
VraR mediated by Stk1 protein phosphorylation." Biochem. Biophys. Res. Commun., 447(1): 165-71. doi: 10.1016/j.bbrc.2014.03.128.

Charlebois, A., M. Jacques, and M. Archambault. 2014. "Biofilm formation of Clostridium perfringens and its exposure to low-dose antimicrobials." Front Microbiol., 5: 183. doi: 10.3389/fmicb.2014.00183.

Collie, R.E., and B.A. McClane. 1998. "Evidence that the enterotoxin gene can be episomal in Clostridium perfringens isolates associated with non-food-borne human gastrointestinal diseases." $J$. Clin. Microbiol., 36(1): 30-6.

Corigliano, M.G., A.M. de Guzmán, and P. V. Stagnitta. 2011. "Characterization of the plasmidic or chromosomal cpe gene and metabolic activities in Clostridium perfringens isolates from food in San Luis--Argentina." Cent. Eur. J. Public Health, 19(1): 46-53.

Cornillot, E., B. Saint-Joanis, G. Daube, S. Katayama, P.E. Granum, B. Canard, and S.T. Cole. 1995. "The enterotoxin gene (cpe) of Clostridium perfringens can be chromosomal or plasmid-borne." Mol. Microbiol., 15(4): 639-47.

Czeczulin, J.R., P.C. Hanna, and B.A. McClane. 1993. "Cloning, nucleotide sequencing, and expression of the Clostridium perfringens enterotoxin gene in Escherichia coli." Infect. Immun., 61(8): 3429-39.

InfoStat, C.W. version 2012. InfoStat Group, FCA, National University of Cordoba, Argentina, http:// www.infostat.com.ar.

Donelli, G., C. Vuotto, R. Cardines, and P. Mastrantonio. 2012. "Biofilm-growing intestinal anaerobic bacteria." FEMS Immunol. Med. Microbiol., 65(2): 318$25 . \quad$ doi: $\quad 10.1111 / \mathrm{j} .1574-$ 695X.2012.00962.x.

Fach, P., and M.R. Popoff. 1997. "Detection of enterotoxigenic Clostridium perfringens in food and fecal samples with a duplex PCR and the slide latex agglutination test." Appl. Environ. Microbiol., 63(11): 4232-6.
Fite, A., S. Macfarlane, E. Furrie, B. Bahrami, J.H. Cummings, D.T. Steinke, and G.T. Macfarlane. 2013. "Longitudinal analyses of gut mucosal microbiotas in ulcerative colitis in relation to patient age and disease severity and duration." J. Clin. Microbiol., 51(3): 849-56. doi: 10.1128/JCM.02574-12.

Jay, James M., Martin J. Loessner, and David Allen Golden. 2005. Modern food microbiol., 7th ed. ed. New York: Springer.

Li, J., and B.A. McClane. 2006. "Comparative effects of osmotic, sodium nitriteinduced, and $\mathrm{pH}$-induced stress on growth and survival of Clostridium perfringens type $\mathrm{A}$ isolates carrying chromosomal or plasmid-borne enterotoxin genes." Appl. Environ. Microbiol., 72(12): 7620-5. doi: 10.1128/AEM.01911-06.

Maier, S.K., S. Scherer, and M.J. Loessner. 1999. "Long-chain polyphosphate causes cell lysis and inhibits Bacillus cereus septum formation, which is dependent on divalent cations." Appl. Environ. Microbiol., 65(9): 3942-9.

Man, J.C. de. 1983. "MPN Tables, Corrected " Eur. J. Appl. Microbiol., Biotechnol., 17: 301-305.

Molina Ubeda, R., and Marcos Diaz. 2002. "Sanitización en la industria enológica." www.alcion.es

Monte, D.F., A.G. Tavares, A.R. Albuquerque, F.C. Sampaio, T.C. Oliveira, O.L. Franco, E.L. Souza, and M. Magnani. 2014. "Tolerance response of multidrugresistant Salmonella enterica strains to habituation to Origanum vulgare L. essential oil." Front Microbiol., 5: 721. doi: 10.3389/fmicb.2014.00721.

Oh, E.T., and J.S. So. 2003. "A rapid method for RNA preparation from Gram-positive bacteria." J. Microbiol. Methods, 52(3): 395-8

Pantaléon, V., S. Bouttier, A.P. Soavelomandroso, C. Janoir, and $\mathrm{T}$. Candela. 2014. "Biofilms of Clostridium species." Anaerobe, 30: 193-8. doi: 10.1016/j.anaerobe.2014.09.010. 
Radhika, B., N.V. Kumar, and D. Sreenivasulu. 2016. "Detection of Clostridium perfringens alpha toxin gene in lambs by loop mediated isothermal amplification." Vet. World, 9(1): 60-4. doi: 10.14202/vetworld.2016.60-64.

Rood, J.I., and S.T. Cole. 1991. "Molecular genetics and pathogenesis of Clostridium perfringens." Microbiol. Rev., 55(4): 621-48.

Sarker, M.R., R.P. Shivers, S.G. Sparks, V.K. Juneja, and B.A. McClane. 2000. "Comparative experiments to examine the effects of heating on vegetative cells and spores of Clostridium perfringens isolates carrying plasmid genes versus chromosomal enterotoxin genes." Appl. Environ. Microbiol., 66(8): 3234-40.

Shandera, W.X., C.O. Tacket, and P.A. Blake. 1983. "Food poisoning due to Clostridium perfringens in the United States." J. Infect. Dis., 147(1): 167-70.

Smedley, J.G., D.J. Fisher, S. Sayeed, G. Chakrabarti, and B.A. McClane. 2004. "The enteric toxins of Clostridium perfringens." Rev. Physiol. Biochem. Pharmacol., 152: 183-204. doi: 10.1007/s10254-004-0036-2.

Sparks, S.G., R.J. Carman, M.R. Sarker, and B.A. McClane. 2001. "Genotyping of enterotoxigenic Clostridium perfringens fecal isolates associated with antibioticassociated diarrhea and food poisoning in North America." J. Clin. Microbiol., 39(3): 883-8.

doi: 10.1128/JCM.39.3.883-888.2001.
Stagnitta, P.V., B. Micalizzi, and A.M. de Guzmán. 2006. "Prevalence of some bacteria yeasts and molds in meat foods in San Luis, Argentina." Cent Eur. J. Public Health, 14(3): 141-4.

Tórtora, J.C. 1984. "Alternative medium for Clostridium perfringens sporulation." Appl. Environ. Microbiol., 47(5): 11724.

Tórtora, J.C., M.S. Pinheiro, and M.C. Pitard. 1986. "Biochemical differentiation between entero-toxigenic heat-sensitive and heat-resistant Clostridium perfringens strains." Microbiol. Immunol., 30(2): 89-95.

Varga, J.J., B. Therit, S.B. Melville. 2008. "Type IV pili and the CcpA protein are needed for maximal biofilm formation by the gram-positive anaerobic pathogen Clostridium perfringens." Infect. Immun., 76(11): 4944-51. doi: 10.1128/IAI.00692-08.

Wang, R., N. Kalchayanand, D.A. King, B.E. Luedtke, J.M. Bosilevac, and T.M. Arthur. 2014. "Biofilm formation and sanitizer resistance of Escherichia coli O157:H7 strains isolated from "high event period" meat contamination." $J$. Food Prot., 77(11): 1982-7. doi: 10.4315/0362-028X.JFP-14-253.

Yantorno, O., A. Bosch, D. Serra, L. Arnal, and S.M Ehling. 2010. "Biofilm en la interfase entre microbiología y biofísica." II TALler Interdisciplianrio Sobre Biofilms Resumenes Fundación Instituto Leloir.

\section{How to cite this article:}

Castro Melina Gabriela, Icazatti Alejandro, Divizia Julia, Vega Alba Edith, Cortiñas Teresa Ines and Stagnitta Patricia Virginia. 2016. Effect of Sanitizers and Glucose on Clostridium perfringens Biofilm Formation and Growth. Int.J.Curr.Microbiol.App.Sci. 5(7): 210-223. doi: http://dx.doi.org/10.20546/ijcmas.2016.507.022 